\title{
PERANAN GURU TERHADAP PEMBINAAN PERILAKU PRO SOSIAL SISWA
}

\section{Oleh :}

\author{
Irma Wirayanti' ${ }^{1)}$, aspin ${ }^{2)}$ \\ 1) 2) Jurusan Bimbingan dan Konseling \\ Fakultas Keguruan dan Ilmu Pendidikan, Universitas Halu Oleo \\ Email: ${ }^{1)}$ irmawirayanti9@gmail.com ${ }^{2)}$ aspin.psi@gmail.com
}

\begin{abstract}
ABSTRAK
Penelitian ini bertujuan untuk mengetahui peranan guru terhadap pembinaan perilaku prososial siswa SMP Negeri 1 Kendari. Penelitian ini merupakan penelitian deskriptif kualitatif. Informan penelitian ini delapan orang,yakni kepala sekolah, wakil kepala sekolah bidang kesiswaan, tiga orang guru, dan tiga orang siswa. Data dikumpulkan melaluiwawancara, observasi dan dokumentasi. Data dianalisis melalui reduksi, display, dan verifikasi data. Hasil penelitian ini adalaha) pembinaan perilaku prososial siswa dilakukan melalui tindakan preventif, represif, dan kuratif, b) tindakan preventif untuk membina perilaku prososial diselenggarakan melalui arahan saat apel pagi dan/ atau upacara bendera, memberi contoh dalam kegiatan belajar, serta melakukan bimbingan kelompok, c) tindakan represif dilakukan untuk menimbulkan efek jera pada siswa, dan d) tindakan kuratif dilakukan sebagai sarana penyembuhan melalui konseling.
\end{abstract}

Kata Kunci: Perilaku Prososial

TEACHER'S ROLE TO DEVELOP STUDENTS PROSOCIAL BEHAVIOR

\begin{abstract}
The aim of this study is to discover whether the role of teacher to making prosocial behavior of SMP Negeri 1 Kendari students. This wasdescriptive qualitative research. Respondents in this researched amounted to eight respondents consist of principal, vice principal of the student field, three teachers, and three students. Data were colletcted by interview, observation, and documentation techniques. Data processed byreduction, display, and verification. The results shown that a) making students prosocial behavior through prevention, repressive, and curative actions, b) prevention actions has done by advice in morning parade and/or flag ceremony, gave examples in learning, and doing group counseling, c)repressive actions was to make a deterrent effects, andd) curative actions as rehabilitation tool through counseling services.
\end{abstract}

Keywords: Prosocial Behavior 


\section{Pendahuluan}

Sekolah merupakan lembaga pendidikan formal yang secara sistematik melaksanakan program bimbingan, pengajaran dan latihan dalam rangka membantu siswa agar mampu mengembangkan potensinya, baik yang menyangkut aspek moral-spiritual, intelektual, emosional maupun sosial. Selain sebagai lembaga pendidikan formal, sekolah merupakan miniatur lingkungan sosial bagi siswa. Sekolah memiliki kewajiban dan tanggung jawab untuk membentuk lingkungan sosial yang kondusif bagi siswa, sehingga sekolah mampu mengantisipasi penyimpangan sosial-psikologis siswa.

Manusia, termasuk siswa adalah makhluk individu dan makhluk sosial. Sebagai makhluk individual, siswa memunyai hubungan dengan dirinya sendiri, adanya dorongan untuk mengabdi kepada dirinya sendiri. Sebagai makhluk sosial, manusia tidak pernah dapat hidup seorang diri (Prayitno \& Amti, 2013: 169). Faturrohman (dalam Yakub, 2011: 213) mengemukakan bahwa setinggi apapun kemandirian seseorang pada saat tertentu dia akan membutuhkan orang lain. Perilaku menolong menggambarkan manusia sebagai makhluk yang tidak egois dan dermawan, mampu untuk memberikan perhatian yang nyata untuk kesejahteraan orang lain dan merasa bahwa dirinya memunyai kemampuan memberikan bantuan pada orang lain.

Perilaku menolong yang dilakukan tanpa pamrih dan tidak mengandung maksud tertentu secara umum dikenal dengan istilah perilaku prososial. Pryor dkk (2010: 59) menjelaskan bahwa perilaku prososial secara umum diterjemahkan sebagai perilaku yang memberi keuntungan bagi orang lain. Perilaku prososial berkembang dimulai sejak masa anak-anak hingga masa dewasa. Semakin bertambah usia seseorang, semakin berkembang kematangan sosial dan tanggung jawab sosialnya. Pada usia remaja, seseorang sudah harus mampu mengembangkan pribadinya, sehingga sesuai dengan nilai etika dan moral dalam bentuk perilaku sosial. Perilaku prososial pada individu yang didasarkan pada nilai etika, moral dan adat-istiadat semestinya menciptakan keharmonisan pada masyarakat tersebut. Namun pada kenyataannya, nilai-nilai prososial yang ada di masyarakat semakin menunjukkan kemunduran. Hal ini juga terjadi pada diri siswa.

Fenomena yang muncul akhir-akhir ini menunjukkan bahwa perilaku siswa tampaknya jauh dari kesan bahwa siswa merupakan individu yang mulai mendewasakan diri dan memiliki minat sosial. Hal ini terlihat dari kenyataan di lapangan bahwa siswa saat ini sering terlibat aksi-aksi kriminal yang membahayakan dan meresahkan masyarakat. Disebutkan oleh Direktorat Ketenagaan Direktorat Jenderal Pendidikan Tinggi Kementerian Pendidikan Nasional (2010: 3) bahwa hal yang menggejala di kalangan pelajar di antaranya adalah tawuran antar pelajar. Di beberapa kota besar tawuran pelajar menjadi tradisi dan membentuk pola yang tetap sehingga di antara mereka membentuk musuh bebuyutan.

Pernyataan tersebut di atas menunjukkan bahwa perilaku siswa yang tampak akhir-akhir ini terlihat bertolak belakang dengan perilaku prososial. Siswa saat ini sibuk dengan aktivitas yang tidak bertujuan dan cenderung menimbulkan keresahan di lingkungan masyarakat. Dalam kenyataannya, banyak perilaku negatif yang muncul dalam keseharian siswa di sekolah, seperti enggan berbagi, minimnya kesadaran untuk saling menolong, kurang peka terhadap penderitaan teman dan bentuk perilaku anti sosial lainnya.

Perilaku prososial sangat dibutuhkan oleh orang-orang yang membutuhkan bantuan seperti siswa yang mengalami masalah. Oleh karena itu, perilaku prososial harus dimiliki oleh setiap siswa. Berdasarkan hasil wawancara dengan Kepala Sekolah, Salah Seorang Guru di SMP Negeri 1 Kendari pada awal Oktober 2018 diperoleh informasi bahwa siswa kurang menunjukkan perilaku prososial. Informan mengemukakan bahwa siswa kebanyakan bersifat individualis, egois, kurang mementingkan keadaan teman yang sedang terkena musibah, kurang peka dalam melihat keadaan lingkungan sekolah yang kotor, enggan secara mandiri dan tulus untuk mengambil sampah yang berserakan, tidak ada inisiatif untuk menanyakan kabar temannya yang beberapa hari tidak masuk sekolah serta kurang menghargai perasaan temannya saat bermain.

Hasil wawancara dengan lima orang siswa, yakni RS, DT, AB, SF, dan AZ juga diperoleh informasi bahwa di sekolah siswa kurang peduli terhadap orang lain, siswa tidak peduli terhadap kondisi kelas yang kotor, susunan kursi yang tidak tertata rapi, masih rendahnya kerja sama yang dilakukan oleh siswa, siswa sibuk dengan urusannya masing-masing bahkan siswa tidak memedulikan teman sekelasnya ketika ada siswa yang tidak masuk sekolah beberapa hari berturutturut. Ketika ditanyakan alasan apa yang 
menyebabkan hal tersebut terjadi siswa secara dominan menganggap bahwa itu sah-sah saja dan menurut mereka itu bukanlah suatu masalah besar. Siswa memandang bahwa siswa lain hanyalah teman, bukan sebagai keluarga. Siswa lain juga mengatakan bahwa mereka enggan berbuat baik kepada yang lain karena siswa lain belum tentu mampu berbuat baik kepada mereka.

Rendahnya perilaku prososial pada siswa tersebut perlu mendapatkan penanganan dari berbagai pihak seperti Kepala Sekolah, Guru Mata Pelajaran, Guru Bimbingan dan Konseling (BK), dan komponen lainnya. Melalui penelitian ini peneliti akan mencoba untuk menganalisa bagaimana peranan guru dalam membina perilaku prososial pada siswa. Alasan untuk menganalisa peranan guru tua adalah karena guru merupakan sosok yang tidak terpisahkan dalam perkembangan kepribadian siswa itu sendiri. Bertolak dari alasan tersebut maka peneliti akan melakukan penelitian dengan judul "Peranan Guru Terhadap Pembinaan Perilaku Prososial Siswa SMP Negeri 1 Kendari”. Tujuan penelitian ini adalah untuk mengetahui bagaimana peranan guru terhadap pembinaan perilaku prososial siswa SMP Negeri 1 Kendari.

\section{Pembinaan Perilaku Prososial}

Istilah pembinaan perilaku prososial dibentuk oleh tiga kata, yakni pembinaan, perilaku dan prososial. Kata "pembinaan" berasal dari kata dasar bina yang artinya membangun, mendirikan, mengusahakan supaya lebih baik. Adapun pembinaan berarti perihal membina, pembaruan, penyempurnaan. Kata "perilaku" diartikan sebagai tanggapan atau reaksi individu terhadap rangsangan atau lingkungan. Selanjutnya, istilah "prososial" atau altruisme menurut Shaffer \& Kipp (2010: 578) adalah keprihatinan tanpa pamrih untuk kesejahteraan orang lain yang diekspresikan melalui tindakan prososial seperti berbagi, kerja sama dan membantu. Hal ini secara tidak langsung berarti bahwa perilaku prososial adalah setiap tanggapan atau reaksi individu yang bermakna tulus bagi orang lain.

Shaffer \& Kipp (2010: 578) mengemukakan bahwa tindakan apa pun yang dimaksudkan untuk memberi manfaat kepada orang lain, seperti berbagi dengan seseorang yang kurang beruntung, menghibur atau menyelamatkan seseorang, kerja sama atau hanya membuat orang lain merasa senang dengan memuji mereka dinamakan perilaku prososial. Mappiare (2006: 257) mendefinisikan perilaku prososial sebagai tindakan individu yang sengaja ditujukan untuk menguntungkan orang lain, ditempuh tanpa adanya pengharapan mendapatkan ganjaran, pada umumnya melibatkan pengorbanan, sebagai hasil dari perkembangan kognitif dan sosial dan jiwa pengorbanan diri macam itu belum terbentuk pada masa kanakkanak sampai anak mencapai usia sekolah dasar, memunyai hubungan dengan taraf perkembangan moral ala Kohlberg.

Baron \& Byrne (dalam Arifin, 2015: 272) menjelaskan bahwa perilaku prososial sebagai segala tindakan yang menguntungkan orang lain. Susanto (2015: 153) mengemukakan bahwa pada dasarnya perilaku prososial sering juga disebut dengan istilah perilaku sosial, yaitu kegiatan yang berhubungan dengan orang lain, kegiatan yang berkaitan dengan pihak lain yang memerlukan sosialisasi dalam hal bertingkah laku yang dapat diterima oleh orang lain, belajar memainkan peran sosial yang dapat diterima oleh orang lain, serta upaya mengembangkan sikap sosial yang layak diterima oleh orang lain. Fokus definisi ini berada pada kegiatan yang bersifat sosial. Arifin (2015: 272) menjelaskan bahwa istilah perilaku prososial diaplikasikan pada tindakan yang tidak menyediakan keuntungan langsung kepada orang yang melakukan tindakan tersebut, bahkan mungkin mengandung tingkat risiko tertentu.

Sears, Freedman, \& Peplau (1985: 47) mendefinisikan perilaku prososial sebagai segala bentuk tindakan yang dilakukan atau direncanakan untuk menolong orang lain, tanpa memerhatikan motif-motif si penolong. Individu dikatakan berperilaku prososial jika individu tersebut menolong individu lain tanpa memerdulikan motifmotif si penolong, timbul karena adanya penderitaan yang dialami oleh orang lain yang meliputi saling membantu, saling menghibur, persahabatan, penyelamatan, pengorbanan, kemurahan hati dan saling membagi.

Berdasarkan uraian di atas dapat dipahami bahwa yang dimaksud dengan pembinaan perilaku prososial adalah serangkaian upaya untuk mengembangkan suatu tindakan atau perilaku positif yang memberi keuntungan terhadap orang lain, dilakukan secara suka rela tanpa ada paksaan dari orang lain tanpa mengharapkan imbalan apapun.

\section{Aspek-aspek perilaku prososial}

Secara umum karakteristik dalam diri setiap individu yang memiliki perilaku prososial adalah memilki kecenderungan untuk menolong 
orang lain. Apabila melihat pengertian perilaku prososial yang merupakan suatu pandangan dan perasaan (senang atau tidak senang) yang disertai dengan kecenderungan untuk bertindak terhadap suatu objek dan dengan cara-cara tertentu yang sesuai dan dikehendaki oleh masyarakat, maka bentuk perilaku prososial dapat berupa pandanganpandangan, perasaan-perasaan dan kecenderungan untuk berperilaku yang positif. Bentuk-bentuk perilaku tersebut dimanifestasikan dalam berbagai cara. Cara-cara tersebut akan menjadi karakteristik-karakteristik perilaku prososial yang dapat dijumpai pada setiap orang yang memunyai perilaku prososial.

$$
\text { Gupta \& Thapliyal (2015: 38) }
$$

mengemukakan bahwa perilaku prososial merupakan perilaku yang ditujukan untuk meningkatkan kesejahteraan orang lain. Individu yang memiliki perilaku prososial memiliki kecenderungan untuk menolong orang lain. Apabila melihat pengertian perilaku prososial sebagai suatu pandangan dan perasaan (senang atau tidak senang) yang disertai dengan kecenderungan untuk bertindak terhadap suatu objek dan dengan cara-cara tertentu yang sesuai dan dikehendaki oleh masyarakat maka bentuk perilaku prososial dapat berupa pandanganpandangan, perasaan-perasaan dan kecenderungan untuk berperilaku yang positif. Bentuk-bentuk perilaku tersebut dimanifestasikan dalam berbagai cara. Cara-cara tersebut akan menjadi aspek-aspek perilaku prososial yang dapat dijumpai pada setiap orang yang memunyai perilaku prososial.

Faktor-faktor yang mempengaruhi perilaku prososial

Sears, Freedman \& Peplau (1985: 51-52) mengemukakan bahwa perilaku prososial menjadi bagian aturan atau norma sosial. Norma tersebut turut menyumbang bagi terjadinya perilaku prososial pada individu. Tiga norma tersebut antara lain:

1. Norma tanggung jawab sosial, norma ini menentukan bahwa seharusnya kita membantu orang lain yang bergantung pada kita. Aturan agama dan moral kebanyakan masyarakat menekankan kewajiban untuk menolong orang lain.

2. Norma timbal balik. Norma ini menyatakan bahwa kita harus menolong orang yang menolong kita. Orang lebih cenderung membantu seseorang yang pernah membantu mereka.
3. Norma keadilan sosial. Norma ini mengatur tentang keadilan dan pembagian sumber daya secara adil. Salah satu prinsip keadilan adalah kesamaan. Menurut prinsip ini, dua orang yang memberikan andil yang sama dalam suatu tugas harus menerima ganjaran yang sama. Bila salah seorang menerima lebih dari yang lain, ia akan mengalami tekanan untuk mencoba memulihkan keadilan dengan mengulangi pembagian ganjaran tersebut.

\section{Peranan Guru}

Istilah peranan guru dibentuk oleh dua kata, yakni peranan dan guru. Surya (2013: 192) menjelaskan bahwa peranan (role) guru merupakan keseluruhan perilaku yang harus dilakukan guru dalam melaksanakan tugasnya sebagai guru. Guru memunyai peranan yang luas, baik di sekolah, di dalam keluarga maupun di masyarakat. Rusman (2017: 170) menjelaskan bahwa guru merupakan faktor penentu yang sangat dominan dalam pendidikan pada umumnya, karena guru memegang peranan dalam proses pembelajaran, di mana proses pembelajaran merupakan inti dari proses pendidikan secara keseluruhan.

Guru dalam bahasa Jawa adalah menunjuk pada seorang yang harus digugu dan ditiru oleh semua murid dan bahkan masyarakat. Harus digugu artinya segala sesuatu yang disampaikan olehnya senantiasa dipercaya dan diyakini sebagai kebenaran oleh semua murid. Sedangkan ditiru artinya seoorang guru harus menjadi suri teladan (panutan) bagi semua muridnya. Istilah patut digugu dan ditiru seringkali dianggap sebagai ungkapan yang mewakili penjelasan betapa mulianya tugas seorang guru. Walaupun ungkapan tersebut bukan ungkapan baku dari kata guru, tapi maknanya memang cukup mewakili hakikat tugas dan misi guru.

Tugas dan tanggung jawab guru terhadap pembinaan perilaku prososial

Guru adalah figur seorang pemimpin. Surya (2013: 192) menjelaskan bahwa guru memegang peranan sentral khususnya pada pendidikan di sekolah. Menurut Setiap guru harus memunyai kompetensi yang memahami bidang studi yang akan diajarkannya. Contohnya, guru agama harus tahu asal-usul dan pengembangan bidang studi yang akan diajarkannya itu. Guru memunyai kekuasaan untuk membentuk dan membangun kepribadian siswa. Jabatan guru sebagai suatu profesi menuntut kepada guru untuk 
mengembangkan profesionalitas diri sesuai perkembangan ilmu pengetahuan dan teknologi. Menurut Peraturan Pemerintah Nomor 19 Tahun 2017 tentang Perubahan Atas Peraturan Pemerintah Nomor 74 Tahun 2008 tentang Guru Pasal 52 bahwa beban kerja guru mencakup 1) merencanakan pembelajaran atau pembimbingan, 2) melaksanakan pembelajaran atau pembimbingan, 3) menilai hasil pembelajaran atau pembimbingan, 4) membimbing dan melatih peserta didik dan 5) melaksanakan tugas tambahan yang melekat pada pelaksanaan kegiatan pokok yang sesuai dengan beban kerja guru.

Rusman (2017: 160) menjelaskan bahwa sebagai profesional maka guru bertugas merencanakan pembelajaran, melaksanakan pembelajaran dan menilai pembelajaran. Di samping itu guru memiliki tugas untuk mendidik, mengajar dan melatih siswa. Tugas guru sebagai pendidik berarti meneruskan dan mengembangkan nilai-nilai hidup kepada siswa. Tugas guru sebagai pengajar berarti meneruskan dan mengembangkan ilmu pengetahuan dan teknologi kepada siswa. Tugas guru sebagai pelatih berarti mengembangkan keterampilan dan menerapkannya dalam kehidupan demi masa depan siswa. Tugastugas tersebut bila dikaitkan dengan pembinaan perilaku prososial maka tugas guru sebagai pendidik adalah menanamkan bagaimana pentingnya memiliki perilaku prososial dalam kehidupan. Sebagai pengajar berarti mencoba mengajarkan dan melatihkan penerapan perilaku prososial dalam kehidupan sehari-hari. Sebagai pelatih berarti mencoba melatih siswa untuk mengembangkan perilaku prososial.

Fungsi guru terhadap pembinaan perilaku prososial Guru memiliki tanggung jawab menjadikan siswa lebih memiliki pengetahuan dan wawasan tentang ilmu pengetahuan dan berperilaku yang baik sesuai dengan nilai-nilai dan norma yang berlaku. Dalam pembinaan perilaku prososial guru memegang fungsi penting. Fungsi-fungsi itu dituangkan dalam bentuk peran-peran yang diemban oleh guru. Fungsi-fungsi tersebut diharapkan mampu dijalankan secara optimal oleh setiap guru. Supardi dkk (2009: 13-24) menyebutkan bahwa fungsi guru di antaranya:

1. Sebagai pendidik. guru merupakan teladan, panutan dan tokoh yang akan diidentifikasikan oleh siswa. Kedudukan sebagai pendidik menuntut guru untuk membekali diri dengan pribadi yang berkualitas berupa tanggung jawab, kewibawaan, kemandirian dan kedisiplinan.

2. Sebagai pengajar. Guru dituntut mampu membuat ilustrasi, membuat definisi, melakukan sintesis, melakukan analisis, mengajukan pertanyaan-pertanyaan kepada siswa, memberikan respon terhadap kegiatan siswa dalam kegiatan pembelajaran, mendengarkan secara aktif apa yang disampaikan siswa, membangun kepercayaan diri siswa, memberikan berbagai macam pandangan secara bervariasi, menyediakan media yang sesuai dengan tuntutan kompetensi mata pelajaran serta membuat pembelajaran aktif, kreatif, edukatif, dan menyenangkan.

3. Sebagai pembimbing. Guru akan mendampingi dan memberikan arahan kepada siswa berkaitan dengan pertumbuhan dan perkembangan pada diri siswa baik yang meliputi aspek kognitif, afektif maupun psikomotor serta pemberian kecakapan hidup kepada siswa baik akademik, vokasional, sosial maupun spiritual.

4. Sebagai pelatih. Guru harus memerhatikan kompetensi dasar yang hendak dicapai pembelajaran, materi pembelajaran, perbedaan individual, latar belakang budaya dan lingkungan tempat siswa tinggal.

5. Sebagai penasihat. Guru harus dapat memberikan konseling sesuai dengan apa yang dibutuhkan siswa baik intensitas maupun masalah-masalah yang dihadapi oleh siswa itu sendiri.

6. Sebagai model dan teladan. Guru dituntut untuk menjadi figur contoh. Guru harus meminimalisir sifat-sifat dan perilaku negatif yang ada dalam dirinya. Guru hendaknya mampu menjadi teladan baik dari gaya berbicara, etos kerja, komunikatif, berpikir logis, kreatif, dan inovatif, maupun cepat dan tegas dalam mengambil keputusan.

7. Sebagai korektor. Guru harus mampu membedakan mana nilai yang baik dan dimana nilai yang buruk. Semua nilai yang baik harus guru pertahankan dan semua nilai yang buruk harus disingkirkan dari jiwa dan watak siswa.

8. Sebagai organisator. Guru memiliki kegiatan pengelolaan akademik, membuat dan melaksanakan program pembelajaran, menyusun tata tertib sekolah, menyusun kalender akademik dan sebagainya. Semuanya 
diorganisasikan, sehingga mencapai efektivitas dan efisiensi dalam belajar pada diri siswa.

9. Sebagai motivator. Guru hendaknya mampu mendorong siswa agar bergairah dan aktif belajar.

10. Sebagai fasilitator. Guru hendaknya dapat menyediakan fasilitas yang memungkinkan kemudahan kegiatan belajar siswa. Guru sebagai fasilitator tidak hanya terbatas menyediakan hal-hal yang sifatnya fisik, tetapi lebih penting lagi adalah bagaimana memfasilitasi siswa agar dapat melakukan kegiatan dan pengalaman belajar serta memperoleh keterampilan hidup.

11. Sebagai pengelola kelas. Guru hendaknya mampu mengelola kelas dengan baik. Kelas yang tidak dikelola dengan baik akan menghambat kegiatan pengajaran.

12. Sebagai mediator. Guru dapat diartikan sebagai penengah dalam proses belajar siswa. Guru sebagai mediator dapat pula diartikan sebagai penyedia media pembelajaran.

13. Sebagai evaluator. Guru adalah sosok penilai hasil belajar siswa. Olehnya itu, guru dituntut untuk menjadi seorang evaluator yang baik dan jujur.

\section{Metode Penelitian}

Penelitian ini dilakukan di SMP Negeri 1 Kendari yang beralamat Jalan Sam Ratulangi Nomor 111, Kendari Barat, Kemaraya, Kendari Barat, Kota Kendari, Sulawesi Tenggara 93121. Penelitian ini dilaksanakan selama tida (3) bulan yakni dimulai dari bulan Oktober sampai bulan Desember 2019.

Jenis penelitian yang digunakan dalam penelitian ini adalah penelitian deskriptif kualitatif. Widodo (2017: 67) mengemukakan bahwa penelitian deskriptif adalah penelitian yang bertujuan untuk mendeskripsikan atau menjelaskan sesuatu hal seperti apa adanya, sehingga memberi gambaran yang jelas tentang situasi-situasi di lapangan apa adanya. Berkaitan dengan itu maka penelitian deskriptif kualitatif merupakan usaha sadar dan sistematis untuk memberikan jawaban terhadap suatu masalah dan/ atau mendapatkan informasi lebih mendalam dan luas terhadap suatu fenomena dengan menggunakan tahap-tahap penelitian dengan pendekatan kualitatif.

Data dalam penelitian ini bersumber dari informan yang berjumlah delapan orang. Informan utama dalam penelitian ini adalah Kepala Sekolah,
Wakil Kepala Sekolah Bidang Kesiswaan, Guru, dan Siswa. Adapun guru yang dimaksud yaitu satu orang guru Bimbingan dan Konseling (BK), satu orang guru Ilmu Pengetahuan Alam (IPA), dan satu orang guru Bahasa Inggris. Informan berikutnya adalah tiga orang siswa SMP Negeri 1 Kendari.

Untuk memperoleh data yang dibutuhkan dalam penelitian ini, maka digunakan alat pengumpul data yang meliputi teknik wawancara mendalam, observasi partisipan dan dokumentasi. Adapun penjelasan masing-masing alat pengumpul data, yakni:

1. Teknik wawancara mendalam

Teknik utama yang digunakan dalam penelitian ini adalah wawancara. Yusuf (2014: 372) mengemukakan bahwa wawancara merupakan percakapan tatap muka (face to face) antara pewawancara dengan sumber informasi, di mana pewawancara bertanya langsung tentang suatu objek yang diteliti dan telah dirancang sebelumnya. Wawancara mendalam dilakukan untuk menelusuri data yang dikemukakan oleh responden secara mendalam dan bersifat individual. Wawancara ini dilakukan dalam waktu dan konteks tepat guna mendapatkan data yang mendalam dan dapat dilakukan berkali-kali sesuai dengan keperluan penelitian tentang masalah yang ditelusurinya. Dengan teknik ini peneliti menjalin hubungan dengan informan secara terbuka, akrab, intensif, dan empati sehingga dapat diperoleh informasi yang akurat dan tidak dibuat-buat.

2. Teknik observasi

Disamping wawancara kasus, digunakan pula teknik observasi dimana peneliti bertindak sebagai observer partisipan. Yusuf (2014: 384) menjelaskan bahwa observer partisipan yaitu bentuk observasi di mana pengamat secara teratur berpartisipasi dan terlibat dalam kegiatan yang diamati. Pengamatan dilakukan terhadap berbagai perilaku dan aktivitas yang dilakukan secara langsung guna memperoleh informasi data tentang peranan guru dan orang tua dalam meningkatkan perilaku prososial siswa.

Observasi adalah pengamatan sistematis terhadap gejala-gejala yang diteliti yang dilakukan untuk memperoleh lebih banyak keterangan dari masalah yang akan diteliti. Observasi juga berfungsi sebagai eksplorasi. Artinya, selain mendapat gambaran yang jelas, 
juga dapat dilakukan pengamatan dari berbagai perubahan yang terjadi dan tertera dalam landasan pemikiran.

3. Studi dokumentasi

Yusuf (2014: 391) menjelaskan bahwa dokumen merupakan catatan atau karya seseorang tentang sesuatu yang sudah berlalu. Teknik ini dilakukan untuk memperoleh data sekunder yang diperlukan dengan jalan mencatat dan mempelajari data-data yang diperlukan serta perihal pendataan lain yang terkait. Kegiatan dokumentasi digunakan untuk memperoleh data pribadi dan lingkungan kasus yang ditetapkan sebagai sasaran penelitian.

Data dalam penelitian ini akan dianalisis secara kualitatif. Teknik analisis data yang digunakan adalah analisis komponensial dengan menggunakan model Miles dan Huberman. Miles dan Huberman (dalam Yusuf, 2014: 407) menjelaskan bahwa dalam penelitian kualitatif data yang terkumpul melalui berbagai teknik pengumpulan data yang berbeda-beda harus segera diproses dan dianalisis sebelum dapat digunakan. Tiap-tiap pengumpulan data disebut sebagai komponen sehingga disebut dengan istilah analisis komponensial. Setelah semua data terkumpul kemudian peneliti melakukan tahapan-tahapan sebagai berikut:

1. Reduksi data

Reduksi data adalah suatu bentuk analisis yang mempertajam, memilih, memfokuskan, membuang, dan mengorganisasikan data dalam suatu cara, di mana kesimpulan akhir dapat digambarkan dan diverifikasikan. Data yang diperoleh dari lapangan ditulis dalam bentuk uraian dan laporan terperinci. Laporan-laporan tersebut direduksi, dirangkum, dipilih hal-hal yang pokok, difokuskan pada hal yang penting, dicari tema atau polanya. Jadi laporan atau catatan lapangan sebagai bahan "mentah" disingkatkan, direduksi, disusun lebih sistematis sehingga lebih mudah dikendalikan. Data yang tidak sesuai dengan fokus penelitian dipisahkan dan hanya akan digunakan jika memang kemudian dibutuhkan oleh peneliti.

2. Penyajian data

Setelah reduksi data dilakukan, peneliti menyajikan data hasil pengamatan dalam bentuk tabel dan berupa uraian singkat yang disimpulkan berdasarkan akumulasi dari perilaku yang tampak pada setiap kali observasi dilakukan. Yusuf (2014: 408) menjelaskan bahwa penyajian data atau display merupakan kumpulan informasi yang telah tersusun yang membolehkan penarikan kesimpulan dan pengambilan tindakan. Hasil wawancara pun dirangkum dan dibuat kesimpulan untuk setiap kali wawancara yang dilakukan terhadap sumber data. Setelah itu data yang diperoleh dari hasil pengamatan dan hasil wawancara disajikan apa adanya dalam bentuk deskripsi atau uraian singkat.

3. Kesimpulan dan verifikasi

Berdasarkan data hasil pengamatan dan wawancara yang telah disusun yang dipandu oleh fokus penelitian dan tujuan penelitian, peneliti dapat menemukan makna dari fakta yang ada, yaitu peranan guru dan orang tua dalam meningkatkan perilaku prososial siswa. Langkah verifikasi yang dilakukan oleh peneliti adalah dengan mengkonfirmasikan kesimpulan hasil pengamatan dan wawancara selama penelitian berlangsung sehingga validitasnya lebih terjamin.

\section{Hasil Penelitian dan Pembahasan \\ Hasil Penelitian}

Berdasarkan hasil pengolahan data yang dilakukan maka diperoleh informasi dari Kepala Sekolah, Guru, dan Siswa bahwa dalam pembinaan perilaku prososial pada siswa di SMP Negeri 1 Kendari, guru melaksanakan tiga peranan. Peranan-peranan tersebut adalah sebagai fasilitator, sebagai korektor, dan sebagai penasihat/ konselor. Peranan fasilitator merupakan peranan yang dilakukan oleh guru dalam rangka memfasilitasi munculnya perilaku prososial pada siswa. Sebagai korektor guru berperan untuk membantu dan menginformasikan kepada siswa tentang baik atau buruknya perilaku siswa. Jika baik diberikan penghargaan dan jika kurang baik maka diberikan hukuman. Sedangkan peran sebagai penasihat/ konselor dilakukan dengan tujuan memberikan pembinaan/ rehabilitasi kepada siswa yang tidak mampu menunjukkan perilaku prososial meskipun telah diberikan hukuman. Berikut uraian mengenai hasil penelitian yang diperoleh.

1. Sebagai fasilitator

Berdasarkan hasil wawancara dengan seluruh informan di SMP Negeri 1 Kendari diperoleh informasi mengenai bagaimana peran guru dalam pembinaan perilaku prososial siswa. Peranan fasilitator dilakukan untuk memberikan informasi yang sebanyak-banyaknya mengenai perilaku prososial. Kegiatan ini dilakukan agar 
siswa mampu memahami, menanamkan dan hingga pada akhirnya mampu melakukan perilaku prososial itu sendiri. Selain itu, kegiatan tersebut juga sebagai tindakan preventif untuk mencegah timbulnya perilaku antisosial sebagai lawan dari perilaku prososial.

Dalam peranannya sebagai fasilitator, yang dilakukan oleh guru adalah menyampaikan arahan ketika menjadi pembina apel pagi dan/ atau upacara bendera ataupun sebelum pembelajaran dimulai, memberikan contohcontoh pada kegiatan belajar serta melakukan layanan bimbingan kelompok khusus guru BK. Berikut uraian mengenai peranan sebagai fasilitator tersebut:

a. Memberikan arahan pada saat apel pagi dan/ atau upacara bendera ataupun sebelum pembelajaran dimulai.

Kegiatan apel pagi merupakan kegiatan rutin siswa sebelum mengikuti kegiatan pembelajaran di kelas. Begitupun dengan kegiatan upacara bendera di setiap hari senin. Pada kegiatan tersebut guru sering memberikan wejangan kepada siswa agar selalu mampu menampilkan perilaku prososial baik kepada siswa, guru, kepala sekolah maupun warga sekolah lainnya. Di samping itu, guru senantiasa memberikan arahan tentang pentingnya perilaku prososial sebelum kegiatan belajar dimulai. Hal-hal tersebut dibuktikan oleh hasil wawancara dengan para informan yang senantiasa berpesan kepada siswa baik dalam apel pagi, upacara bendera (jika menjadi pembina upacara), maupun sebelum kegiatan pembelajaran dimulai agar para siswa selalu menunjukkan perilaku-perilaku positif tanpa balas jasa kepada orang di sekitarnya. Hal itu penting karena zaman sekarang persoalan krisis moral adalah masalah utama dalam kehidupan.

Berdasarkan uraian tersebut, dapat dipahami bahwa guru SMP Negeri 1 Kendari senantiasa memberikan arahan kepada siswa untuk berperilaku prososial melalui kegiatan apel pagi, upacara bendera, ataupun sebelum kegiatan belajar dimulai.

b. Memberikan contoh-contoh pada kegiatan belajar.

Pembinaan perilaku prososial pula diselenggarakan dalam kegiatan belajar. Guru senantiasa memberikan materi pelajaran yang bisa dihubungkan dengan perilaku prososial. Hal ini terangkum dalam hasil wawancara dengan informan bahwa seringkali guru mengajar dengan memberikan contoh-contoh yang tidak jauh dari tolong-menolong, ikhlas, jujur, dermawan dan sebagainya. Semua itu dilakukan agar siswa-siswa menjadi anak didik yang baik di masa depan.

Hal-hal yang disampaikan oleh informan tersebut menunjukkan bahwa guru SMP Negeri 1 Kendari senantiasa mencoba membina perilaku prososial siswa tidak hanya melalui kegiatan apel maupun upacara tetapi juga membina perilaku prososial siswa dalam kegiatan belajar melalui menghubungkan isi materi dengan perilaku prososial.

c. Pemberian layanan bimbingan kelompok

Upaya lain yang juga dilakukan dalam membina perilaku prososial adalah melakukan layanan bimbingan kelompok. Upaya ini secara khusus dilakukan oleh guru BK. Melalui kegiatan bimbingan kelompok, guru BK membahas topik-topik yang berkaitan dengan perilaku prososial agar siswa mampu memperoleh wawasan dan nilai-nilai baru mengenai perilaku prososial itu sendiri

\section{Sebagai korektor}

Dalam upaya pembinaan perilaku prososial maka guru diharapkan mampu membantu siswa dalam membedakan mana yang baik dan mana yang buruk. Meskipun telah berperan sebagai fasilitator ada kalanya siswa memuncukan perilaku yang bertentangan dengan perilaku prososial. Untuk itu bentuk tindakan koreksi yang dilakukan adalah melalui tindakan represif. Tindakan represif diberikan jika terdapat siswa yang menunjukkan perilaku yang bertentangan dengan perilaku prososial itu sendiri. Tindakan ini diberikan berdasarkan berat atau ringannya pelanggaran yang dilakukan oleh siswa. Tindakan ini bertujuan menimbulkan efek jera bagi siswa yang kurang mampu berperilaku prososial seperti berkelahi dengan teman, menghina teman, membuat teman menangis dan sebagainya. Tindakan hukuman yang diberikan oleh guru senantiasa dilakukan dengan berkoordinasi dengan wakil kepala sekolah bidang kesiswaan. Di sekolah ini menyangkut pemberian hukuman bukan merupakan ranah BK. 
Siswa yang melanggar makna perilaku prososial akan diberikan hukuman yang bervariasi mulai dari menulis surat pernyataan bahwa tidak akan mengulangi lagi perbuatannya, pemanggilan orang tua, skorsing, bahkan dikeluarkan dari sekolah. Tindakan represif lain yang digunakan dalam pembinaan perilaku prososial siswa adalah memberikan skorsing dengan jangka waktu yang telah disepakati.

Berdasarkan pernyataan dari informan tersebut, dapat dipahami bahwa dalam peranannya sebagai korektor maka bentuk pembinaan perilaku prososial yang dilakukan oleh guru kepada siswa melalui pemberian hukuman bagi siswa yang melanggar. Pemberian hukuman dalam rangka pembinaan perilaku prososial siswa SMP Negeri 1 Kendari berada pada wakil kepala sekolah bidang kesiswaan yang berkoordinasi dengan guru dan pembina OSIS. Tindakan ini untuk mengingatkan kepada siswa bahwa yang dilakukan adalah hal yang kurang baik sehingga siswa mampu menyadari kesalahannya itu.

\section{Pembahasan}

Berdasarkan hasil pengolahan data yang dilakukan maka diperoleh informasi bahwa dalam pembinaan perilaku prososial pada siswa di SMP Negeri 1 Kendari guru melaksanakan tiga peranan. Peranan-peranan tersebut adalah sebagai fasilitator, sebagai korektor, dan sebagai penasehat/ konselor.

Perilaku prososial perlu dibina dan dikembangkan pada siswa agar siswa mampu menjadi individu yang bermanfaat bagi orang lain di masa mendatang. Berdasarkan hasil penelitian diketahui bahwa dalam pembinaan perilaku prososial siswa SMP Negeri 1 Kendari maka guru berperan sebagai fasilitator, korektor, dan penasihat/ konselor. Peranan tersebut pada dasarnya dijalankan melalui tindakan preventif, represif dan kuratif.

Hasil penelitian ini sejalan dengan penelitian Wardani \& Trisanti (2015) yang menunjukkan bahwa konseling sebaya efektif untuk meningkatkan perilaku prososial siswa. Relevansi antara penelitian ini dengan penelitian yang akan dilakukan terletak pada kajian perilaku prososial.

Menurut Zakaria (2016), upaya guru IPS dalam mengembangkan perilaku prososial meliputi dua kegiatan utama. 1) kegiatan pembelajaran dalam kelas (menginternalisasikan perilaku prososial menggunakan model/ metode pembelajaran, mengintegrasikan langsung pada materi-materi relevan, penugasan kelompok, penguatan langsung). 2) kegiatan pembelajaran diluar kelas (kegiatan ekstrakulikuler, menjadi wali kelas, study tour). Relevansi antara penelitian ini dengan penelitian yang akan dilakukan terletak pada kajian perilaku prososial dan upaya guru untuk meningkatkannya.

Sebagai fasilitator maka yang dilakukan guru untuk membina perilaku prososial antara lain memberikan arahan saat apel pagi, upacara bendera, memberikan contoh dalam setiap materi pelajaran serta khusus bagi guru BK, mereka melakukan layanan bimbingan kelompok. $\mathrm{Ke}$ semua tindakan ini dilakukan dengan tujuan untuk mencegah terjadinya perilaku yang tidak mencerminkan perilaku prososial. Tindakan ini melambangkan bahwa guru hendaknya menjadi seorang pendidik.

Layanan bimbingan kelompok digunakan sebagai upaya meminimalisir proses identifikasi yang kurang tepat oleh siswa. Melalui layanan bimbingan kelompok siswa akan mendiskusikan topik-topik berhubungan dengan perilaku prososial sehingga siswa mampu meramalkan apa yang akan terjadi sebelum siswa berbuat.

\section{Kesimpulan dan Saran \\ Kesimpulan}

Berdasarkan hasil penelitian dan pembahasan, dapat ditarik kesimpulan bahwa permbinaan perilaku sosial siswa di SMP Negeri 1 Kendari dilakukan melalui 3 cara, yakni: 1) upaya preventif, 2) tindakan kuratif dan 3) tindakan represif. Upaya preventif, dilakukan dengan beberapa cara antara lain dengan memberikan arahan pada saat apel pagi dan/ atau upacara bendera ataupun sebelum pembelajaran dimulai, memberikan contoh-contoh pada kegiatan belajar serta pemberian layanan bimbingan kelompok. Tindakan represif dilakukan dengan tujuan memberikan efek jera sedangkan tindakan kuratif dilakukan sebagai sarana penyembuhan pada siswa melalui kegiatan konseling.

\section{Saran}

Beberapa saran yang diberikan berdasarkan hasil penelitian ini antara lain:

1. Begi Guru Mata Pelajaran, agar sekiranya mampu lebih dekat dan akrab dengan siswa agar mampu lebih terbuka dan belajar banyak dari guru. 
2. Bagi Guru BK, untuk lebih mengasah keterampilan dalam memberikan pelayanan konseling.

3. Bagi peneliti selanjutnya, jika hendak melakukan penelitian yang berkaitan dengan tema perilaku prososial agar mampu lebih mengelaborasi tema tersebut sehingga diperoleh pengajian yang lebih komprehensif.

\section{Daftar Pustaka}

Abidin, Zaenal. (2010). Dasar-dasar Bimbingan dan Konseling. Yogyakarta: STAIN Press Purwokerto.

Afolabi, O.A. (2014). Psychosocial Predictors Of Prosocial Behaviour Among A Sample Of Nigerian Undergraduates. European Scientific Journal, 10 (2), 241 - 266.

Ardi, M. (2012). Pengaruh Pemberian Hukuman Terhadap Disiplin Siswa Dalam Belajar (Penelitian Eksperimen di Kelas VIII Sekolah Menengah Pertama Negeri 1 Nanga Tebidah Kecamatam Kayan Hulu Kabupaten Sintang). Jurnal Eksos, 8 (1), 61 -72 .

Gupta, D. \& Thapliyal, G. (2015). A Study Of Prosocial Behaviour and Self Concept Of Adolescents. I-manager's Journal on Educational Psychology, 9 (1), 38 - 45.

Hanurawan. (2018). Psikologi Sosial Terapan. Depok: PT. Rajagrafindo Persada.

Kartono, Kartini. (2001). Patologi Sosial: Jilid I. Jakarta: Raja Grafindo.

(2017). Patologi Sosial 2: Kenakalan Remaja. Jakarta: Rajawali Pers.

Peraturan Pemerintah Nomor 19 Tahun 2017 tentang Perubahan Atas Peraturan Pemerintah Nomor 74 Tahun 2008 tentang Guru.

Ratnawati, Ace dan Anwar Nurdin, 2004. Perilaku Remaja di Kelurahan Cigadung, Kecamatan Cibeunying-Kaler. Jakarta: Pusat Penelitian Permasalahan Kesejahteraan Sosial, Badan Pelatihan dan Pengembangan Sosial, Departemen Sosial RI.
Sugiyono. (2015). Metodologi Penelitian. Bandung: Alvabeta.

Tohirin. (2007). Bimbingan Konseling di Sekolah dan Madrasah. Jakarta: Raja. Grafindo Persada.

Undang-undang RI Nomor 20 Tahun 2003 tentang Sistem Pendidikan Nasional.

Wardani, S.Y. \& Trisnani, R.P. (2015). Konseling Sebaya untuk Meningkatkan Perilaku Prososial Siswa. Psikopedagogia, 4 (2), 87 92.

Zakaria, A.F. (2016). Studi Tentang Upaya Guru IPS dalam Mengembangkan Perilaku Prososial dan Mengurangi Perilaku Bullying Siswa di SMP (Studi Kasus Pada Guru IPS SMP PGRI 1 Jatinangor Kab. Sumedang Jawa Barat). JPIS, Jurnal Pendidikan Ilmu Sosial, 25 (1), 117 - 124. 